\title{
Papers
}

\section{Risk of cardiovascular disease measured by carotid intima-media thickness at age 49-51: lifecourse study}

\author{
Douglas Lamont, Louise Parker, Martin White, Nigel Unwin, Stuart M A Bennett, Melanie Cohen, \\ David Richardson, Heather O Dickinson, Ashley Adamson, K G M M Alberti, Alan W Craft
}

\begin{abstract}
Objective To quantify the direct and indirect effects of fetal life, childhood, and adult life on risk of cardiovascular disease at age 49-51 years.

Design Follow up study of the "Newcastle thousand families" birth cohort established in 1947.

Participants 154 men and 193 women who completed a health and lifestyle questionnaire and attended for clinical examination between October 1996 and December 1998.
\end{abstract}

Main outcome measures Correlations between mean intima-media thickness of the carotid artery (carotid intima-media thickness) and family history, birth weight, and socioeconomic position around birth; socioeconomic position, growth, illness, and adverse life events in childhood; and adult socioeconomic position, lifestyle, and biological risk markers. Proportions of variance in carotid intima-media thickness that were accounted for by each stage of the lifecourse.

Results Socioeconomic position at birth and birth weight were negatively associated with carotid intima-media thickness, although only social class at birth in women was a statistically significant covariate independent of adult lifestyle. These early life variables accounted directly for $2.2 \%$ of total variance in men and $2.0 \%$ in women. More variation in carotid intima-media thickness was explained by adult socioeconomic position and lifestyle, which accounted directly and indirectly for $3.4 \%$ of variance in men (95\% confidence interval $0.5 \%$ to $6.2 \%$ ) and $7.6 \%$ in women (2.1\% to $13.0 \%)$. Biological risk markers measured in adulthood independently accounted for a further $9.5 \%$ of variance in men $(2.4 \%$ to $14.2 \%)$ and $4.9 \%$ in women $(1.6 \%$ to $7.4 \%)$.

Conclusions Adult lifestyle and biological risk markers were the most important determinants of the cardiovascular health of the study members of the Newcastle thousand families cohort at age 49-51 years. The limited overall effect of early life factors may reflect the postwar birth year of this cohort.

\section{Introduction}

Risk of disease in later life may be "programmed" by impaired development in utero due to suboptimal fetal nutrition, ${ }^{1}$ but infant and childhood experience may also determine adult health and risk of disease independently of factors operating in fetal life or adulthood. ${ }^{23}$ The antecedents of adult disease should therefore be studied across the whole lifecourse. ${ }^{4}$ The "Newcastle thousand families" cohort-all 1142 children born in May and June 1947 to mothers resident in the city of Newcastle upon Tyne-provides such an opportunity. Two thirds of these children were followed to the age of 15 years, and detailed information was collected on their health, growth, and socioeconomic circumstances. ${ }^{5}$

We used these early life data and recent information on the health and lifestyle of the study members as adults to quantify the direct and indirect effects $^{6}$ of characteristics of fetal life, childhood, and adult life on risk of cardiovascular disease, as measured by the intima-media thickness of the carotid artery (carotid intima-media thickness) at age 49-51 years. Carotid intima-media thickness is an established measure of preclinical atherosclerosis ${ }^{7}$ and a predictor of incident coronary heart disease and stroke. ${ }^{8}$

\section{Participants and methods}

Participants were cohort members who either contacted the project team in response to media publicity or were traced through the NHS central register. Data on fetal life, infancy, and childhood were abstracted from existing records. Data on adult health and lifestyle were obtained from questionnaires completed by the participants between October 1996 and December 1998. Biological risk markers were measured over the same period at the Royal Victoria Infirmary, Newcastle. Ethical approval for the study was obtained from the local research ethics committees.

Clinical examination and laboratory procedures Carotid intima-media thickness was measured bilaterally by $\mathrm{B}$ mode ultrasonography (7 MHz linear array, Acuson 128/XP-10) at three locations in the common and internal carotid arteries ${ }^{10}$ and averaged over the six sites. Height, weight, and waist and hip circumferences were measured according to the protocol of the World Health Organisation monitoring trends and determinants in cardiovascular disease (MONICA) project. ${ }^{11}$ Blood pressure was measured according to the guidelines of the British Hypertension Society. ${ }^{12}$

\begin{tabular}{|c|}
\hline $\begin{array}{l}\text { Department of } \\
\text { Child Health, } \\
\text { University of } \\
\text { Newcastle, Sir James } \\
\text { Spence Institute of } \\
\text { Child Health, Royal } \\
\text { Victoria Infirmary, } \\
\text { Newcastle upon } \\
\text { Tyne NE1 4LP }\end{array}$ \\
\hline $\begin{array}{l}\text { Douglas Lamont } \\
\text { senior research } \\
\text { associate in } \\
\text { epidemiology }\end{array}$ \\
\hline $\begin{array}{l}\text { Louise Parker } \\
\text { senior lecturer in } \\
\text { epidemiology }\end{array}$ \\
\hline $\begin{array}{l}\text { Melanie Cohen } \\
\text { research associate }\end{array}$ \\
\hline $\begin{array}{l}\text { Heather O } \\
\text { Dickinson } \\
\text { senior research } \\
\text { associate }\end{array}$ \\
\hline $\begin{array}{l}\text { Alan W Craft } \\
\text { professor }\end{array}$ \\
\hline $\begin{array}{l}\text { Department of } \\
\text { Epidemiology and } \\
\text { Public Health, } \\
\text { School of Health } \\
\text { Care Sciences, } \\
\text { Medical School, } \\
\text { University of } \\
\text { Newcastle, } \\
\text { Newcastle upon } \\
\text { Tyne NE1 4HH }\end{array}$ \\
\hline $\begin{array}{l}\text { Martin White } \\
\text { senior lecturer in } \\
\text { public health }\end{array}$ \\
\hline $\begin{array}{l}\text { Nigel Unwin } \\
\text { senior lecturer in } \\
\text { epidemiology } \\
\text { continued over }\end{array}$ \\
\hline BMJ 2000;320:273-8 \\
\hline $\begin{array}{l}\text { website } \\
\text { extra }\end{array}$ \\
\hline $\begin{array}{l}\text { Additional } \\
\text { acknowledgments } \\
\text { and a table } \\
\text { detailing the } \\
\text { representativeness } \\
\text { of the cohort by } \\
\text { weight and social } \\
\text { class at birth } \\
\text { appear on the } \\
\text { BMJ's website }\end{array}$ \\
\hline
\end{tabular}

Department of University of Newcastle, Sir James Spence Institute of Health, Royal Victoria Infirmar Tyne NE1 4LP Douglas Lamont associate in epidemiology Louise Parker epidemiology

Melanie Cohen research associate

Heather $\mathrm{O}$

Dickinson senior research professor

Department of Epidemiology and School of Health Care Sciences, Medical Schoo, Newcastle, Newcastle upon Tyne NE1 4HH Nigel Unwin senior lecturer in epidemiology 
Department of Medicine, Medical School, University of Newcastle

Nigel Unwin senior lecturer

Stuart M A Bennett clinical research associate

K G M M Alberti professor

Department of Radiology, Royal Victoria Infirmary, Newcastle

David Richardson consultant

Human Nutrition Research Centre,

University of

Newcastle

Ashley Adamson lecturer

Correspondence to: D Lamont d.w.lamont@ncl. ac.uk
A 12 lead electrocardiogram was recorded and Minnesota coded..$^{13}$

The concentrations of total cholesterol, high density lipoprotein cholesterol, and triglycerides in serum were measured directly using standard enzymatic methods, and the concentration of low density lipoprotein cholesterol was calculated. ${ }^{14}$ Plasma glucose concentration after an oral glucose load of $75 \mathrm{~g}$ was measured immediately with an analyser (YSI 2300 Stat Plus, Yellow Springs Instruments, Farnborough, UK). Serum insulin concentration was determined by enzyme linked immunosorbent assay (ELISA). Plasma fibrinogen concentration was derived from prothrombin time using an automatic coagulator.

\section{Measurement of early life experience}

Relevant family history was defined as death from cardiovascular disease or clinically diagnosed angina, ischaemic heart disease, or stroke in a parent or sibling before the age of 55 years in men and 65 years in women. ${ }^{15}$ Socioeconomic status at birth was measured by father's occupational social class, and at ages 5 and 10 years by that of the main wage earner of the household. Housing conditions at birth and at ages 5 and 10 years were scored for the presence of up to three or more of: overcrowding; lack of hot water; shared toilet; and dampness or poor repair. Experience of adverse life events in childhood (from birth to age 15 years) was scored for the presence of up to two or more of: parental divorce or separation; death of a parent; parental incapacity through illness; serious debt; and parental criminal activity or cruelty. The number of recorded episodes of infectious illness from birth to age 15 years was calculated.

Growth data were converted to standard deviation scores comparative to contemporary growth standards. ${ }^{16}{ }^{17}$ Birth weights were adjusted for gestational age ${ }^{18}$ Catch up growth in childhood ${ }^{19}$ was measured as the difference in standard deviation scores for birth weight and height at age 49-51 years, adjusted for achieved adult height and birth weight. ${ }^{20}$
Measurement of adult socioeconomic position and lifestyle

Occupational social class of the main wage earner in the household, the number of pack years of cigarettes smoked, and four categories ${ }^{21}$ of self reported alcohol consumption were derived from questionnaire data. Responses to the European prospective investigation of causes and nutrition (EPIC) food frequency questionnaire ${ }^{22}$ were analysed to provide continuous estimates of the proportion of total dietary energy accounted for by fatty acids. Classification of physical activity and exercise level was based on that used in the Medical Research Council's national survey of health and development. ${ }^{23}$

\section{Statistical analysis}

Twins were excluded from all analyses. Measures of glucose, insulin, fibrinogen, high density lipoprotein cholesterol, and triglyceride concentration had skewed distributions and were $\log$ transformed. Values of carotid intima-media thickness for each value of all covariates were approximately normally distributed and homoscedastic and were not transformed. Physical inactivity and family history were defined as binary variables. Exercise level, alcohol consumption, adverse life events in childhood, and all measures of social class and housing conditions were defined as ordinal variables and assessed for trend. Missing values were imputed by multiple regression. ${ }^{24}$

Variables were grouped within a conceptual framework $^{25}$ according to stage of lifecourse (figure). Associations between carotid intima-media thickness and individual explanatory variables were estimated by multiple linear regression. The percentage of total variance in carotid intima-media thickness accounted for by each group directly (pathways 1-5 on figure) was estimated by the difference in $\mathrm{R}^{2}$ between models with and without the group of interest and including all other variables. The overall contribution of early life variables-both directly (pathways 1-3) and indirectly through adult lifestyle (pathway $\mathrm{C}$ ) - and biological risk markers (pathway $\mathrm{D}$ ) was estimated by $\mathrm{R}^{2}$ from a model including these variables alone. The overall contribution

Table 1 Descriptive statistics for continuous variables

\begin{tabular}{|c|c|c|c|c|c|c|c|c|}
\hline \multirow[b]{2}{*}{ Variable } & \multicolumn{4}{|c|}{ Men } & \multicolumn{4}{|c|}{ Women } \\
\hline & $\begin{array}{c}\text { No of } \\
\text { participants* }\end{array}$ & Range & Mean (SD) & $\begin{array}{c}\text { Median } \\
\text { (interquartile range) }\end{array}$ & $\begin{array}{c}\text { No of } \\
\text { participants* }\end{array}$ & Range & Mean (SD) & $\begin{array}{c}\text { Median } \\
\text { (interquartile range) }\end{array}$ \\
\hline Carotid intima-media thickness (mm) & 154 & $0.55-1.60$ & $0.80(0.17)$ & $0.76(0.68-0.87)$ & 193 & $0.38-1.28$ & $0.74(0.15)$ & $0.72(0.65-0.80)$ \\
\hline Cigarette smoking (pack years) & 152 & $0.1-73 \dagger$ & $23.7(16.9) \dagger$ & $22.1(8.3-33.5) \dagger$ & 193 & $0.1-40.5 \dagger$ & $16.1(10.8) \dagger$ & $16.6(5.7-24.0) \dagger$ \\
\hline Total energy from fat $(\%)$ & 149 & $18.7-49.4$ & $33.8(5.9)$ & $34.5(29.5-38.0)$ & 184 & $18.0-50.8$ & $32.4(6.3)$ & $32.6(28.7-36.7)$ \\
\hline Waist to hip ratio & 154 & $0.78-1.08$ & $0.96(0.06)$ & $0.95(0.92-0.99)$ & 193 & $0.68-0.97$ & $0.80(0.06)$ & $0.79(0.75-0.84)$ \\
\hline Systolic blood pressure $(\mathrm{mmHg}) \ddagger$ & 139 & $70-185$ & $127.0(15.9)$ & $125(118-135)$ & 170 & $99-186$ & $122.5(14.9)$ & $120.5(111-130)$ \\
\hline $\begin{array}{l}\text { Serum low density lipoprotein } \\
\text { cholesterol }(\mathrm{mmol} / \mathrm{l}) \neq \S \\
\end{array}$ & 152 & $1.20-8.06$ & $4.06(1.34)$ & $4.00(3.20-4.89)$ & 191 & $0.38-7.55$ & $3.67(1.24)$ & $3.50(2.85-4.46)$ \\
\hline $\begin{array}{l}\text { Serum high density lipoprotein } \\
\text { cholesterol }(\mathrm{mmol} / \mathrm{l}) \ddagger \S\end{array}$ & 152 & $0.47-2.10$ & 0.969 & $0.99(0.79-1.18)$ & 191 & $0.51-2.53$ & $1.14 \pi$ & $1.18(0.88-1.40)$ \\
\hline Serum triglycerides $(\mathrm{mmol} / \mathrm{l})$ & 152 & $0.31-9.64$ & 1.239 & $1.25(0.79-1.83)$ & 191 & $0.25-3.60$ & $0.93 \rrbracket$ & $0.88(0.63-1.35)$ \\
\hline Plasma fibrinogen $(\mathrm{g} / \mathrm{l}) \ddagger$ & 154 & $1.4-5.0$ & $2.81 \rrbracket$ & $2.75(2.40-3.20)$ & 189 & $1.3-5.0$ & $2.95 \Uparrow$ & $2.90(2.50-3.50)$ \\
\hline 2 Hour plasma glucose $(\mathrm{mmol} / \mathrm{l}) \S$ & 151 & $2.31-13.30$ & $5.51 \rrbracket$ & $5.54(4.77-6.45)$ & 189 & $3.23-11.50$ & $5.54 \Uparrow$ & $5.72(4.59-6.45)$ \\
\hline Fasting serum insulin $(\mathrm{mU} / \mathrm{l}) \S$ & 148 & $1.4-29.6$ & $7.88 \rrbracket$ & $7.7(5.65-12.0)$ & 185 & $1.2-23.7$ & 6.199 & $6.0(4.5-8.6)$ \\
\hline Episodes of infectious illness in childhood & 131 & $3-50$ & $17.1(8.5)$ & $15(10-22)$ & 162 & $5-47$ & $17.1(7.6)$ & $16(12-21)$ \\
\hline
\end{tabular}

*Excludes twins. †Excludes 50 men and 87 women who had never smoked.

‡Measurements of lipids, fibrinogen, and blood pressure exclude participants taking lipid lowering drugs, warfarin, or antihypertensives respectively.

§Measurements of lipids, insulin, and glucose exclude participants taking drugs for diabetes. १Mean of log transformed values (geometric mean of raw data). 


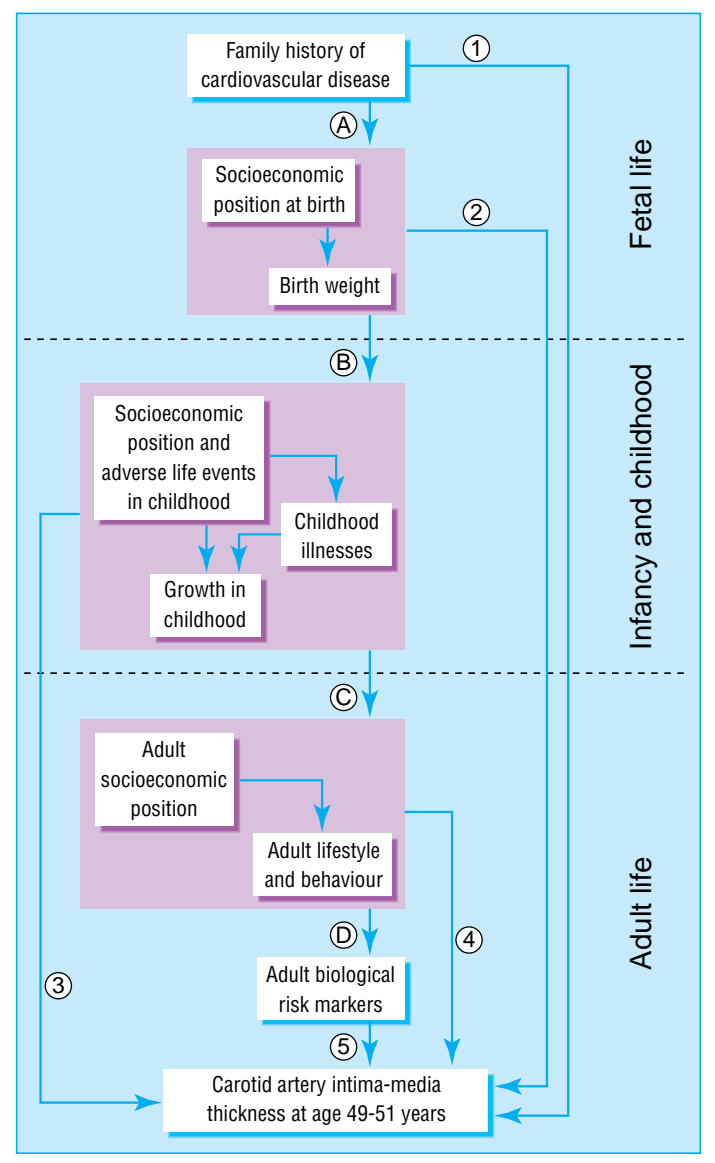

Conceptual framework for fetal, infant, childhood, and adult influences on risk of cardiovascular disease at age 49-51 years. Pathways 1-5 are direct effects of each stage of lifecourse on carotid intima-media thickness, and pathways A-D are indirect effects mediated through later stages of lifecourse. Adult lifestyle and behaviour variables are cigarette smoking, alcohol consumption, exercise level, physical inactivity, and percentage total energy from fat. Adult biological risk markers are waist to hip ratio, systolic blood pressure, concentrations of serum low density lipoprotein cholesterol, serum high density lipoprotein cholesterol, serum triglycerides, plasma fibrinogen, 2 hour plasma glucose, and fasting insulin at time of screening

of adult lifestyle variables, both directly (pathway 4) and indirectly through biological risk markers (pathway D), was estimated by the difference in $\mathrm{R}^{2}$ between models with and without this group and including all other variables except risk markers. Statistical analyses were carried out with STATA statistical software (release 5.0, Stata, College Station, TX).

\section{Results}

Of the original 1142 cohort members, 832 were traced $(89.3 \%$ of the surviving sample of 932 children whose families remained in Newcastle for at least the first year). Of these, $574(68.9 \%)$ completed the questionnaire and $412(49.5 \%)$ attended for clinical examination. Ultrasound measurements of the carotid artery were available for 347 singleton study members (154 men and 193 women). This sample did not differ significantly from the original cohort in terms of birth weight $\left(\chi^{2}=5.50(5 \mathrm{df}), \mathrm{P}=0.36\right)$ and social class at $\operatorname{birth}\left(\chi^{2}=7.14(4 \mathrm{df}), \mathrm{P}=0.13\right)$.

Mean carotid intima-media thickness was $0.77 \mathrm{~mm}$ (0.80 $\mathrm{mm}$ in men and $0.74 \mathrm{~mm}$ in women) (table 1$)$.
Overall, 29 participants had electrocardiographic evidence of cardiac ischaemia (Minnesota codes 1.1-1.3, 4.1-4.3, 5.1-5.3, 7.1). Forty five participants had definite or possible angina and 27 had severe chest pain according to the Rose questionnaire. ${ }^{26}$ Mean carotid intima-media thickness was $0.79 \mathrm{~mm}(95 \%$ confidence interval 0.75 to 0.83 ) in 35 men and 36 women with electrocardiographic evidence of ischaemia or who self reported angina or severe chest pain, or both, and $0.76 \mathrm{~mm}(0.74$ to 0.78$)$ in those who were asymptomatic (one tailed, $\mathrm{P}=0.06$ ).

\section{Fetal, infant, and childhood influences}

Social class at birth in women and birth weight in men displayed the strongest associations with carotid intima-media thickness (unadjusted standardised regression coefficients $\mathrm{b}=-0.16, \quad \mathrm{P}=0.02$ and $\mathrm{b}=-0.17, \mathrm{P}=0.03$ respectively) (tables 2 and 3 ). All other early life variables, including social class and

Table 2 Descriptive statistics for categorical variables

\begin{tabular}{|c|c|c|}
\hline Variable & $\begin{array}{c}\text { No }(\%) \text { of } \\
\text { men }\end{array}$ & $\begin{array}{c}\text { No }(\%) \text { of } \\
\text { women }\end{array}$ \\
\hline Social class at birth: & $n=149$ & $n=190$ \\
\hline 1,2 & $19(13)$ & $16(8)$ \\
\hline 3 & $84(56)$ & $128(67)$ \\
\hline 4,5 & $46(31)$ & $46(24)$ \\
\hline Social class at age 5 years: & $\mathrm{n}=138$ & $\mathrm{n}=170$ \\
\hline 1,2 & $11(8)$ & $12(7)$ \\
\hline $3 N$ & $15(11)$ & $21(12)$ \\
\hline $3 \mathrm{M}$ & $61(44)$ & $75(44)$ \\
\hline 4,5 & $51(37)$ & $62(37)$ \\
\hline Social class in adulthood: & $\mathrm{n}=146$ & $\mathrm{n}=180$ \\
\hline 1,2 & $70(48)$ & $94(52)$ \\
\hline $3 \mathrm{~N}$ & $15(10)$ & $26(14)$ \\
\hline $3 \mathrm{M}$ & $45(31)$ & $33(18)$ \\
\hline 4,5 & $16(11)$ & $27(15)$ \\
\hline Housing conditions score at birth*: & $\mathrm{n}=152$ & $\mathrm{n}=193$ \\
\hline 0 & $71(47)$ & $92(48)$ \\
\hline 1 & $37(24)$ & $54(28)$ \\
\hline 2 & $28(18)$ & $23(12)$ \\
\hline 3 or more & $16(11)$ & $24(12)$ \\
\hline Housing conditions score at age 5 years*: & $\mathrm{n}=139$ & $\mathrm{n}=172$ \\
\hline 0 & $70(50)$ & $89(52)$ \\
\hline 1 & $41(30)$ & $50(29)$ \\
\hline 2 & $17(12)$ & $20(12)$ \\
\hline$\geqslant 3$ & $11(8)$ & $13(8)$ \\
\hline Adverse life events in childhood: & $\mathrm{n}=131$ & $\mathrm{n}=162$ \\
\hline None & $82(63)$ & $90(56)$ \\
\hline 1 & $39(30)$ & $51(32)$ \\
\hline$\geqslant 2$ & $10(8)$ & $21(13)$ \\
\hline \multirow[t]{2}{*}{ Family history of cardiovascular disease } & $n=152$ & $n=193$ \\
\hline & $28(18)$ & $47(24)$ \\
\hline Exercise level at age $49-51$ years: & $\mathrm{n}=152$ & $\mathrm{n}=192$ \\
\hline Most active & $24(16)$ & $28(15)$ \\
\hline Less active & $32(21)$ & $49(26)$ \\
\hline Least active & $96(63)$ & $115(60)$ \\
\hline \multirow[t]{2}{*}{ Physically inactive at age $49-51$ years } & $\mathrm{n}=150$ & $\mathrm{n}=186$ \\
\hline & $12(8)$ & $25(13)$ \\
\hline Alcohol consumption†: & $\mathrm{n}=152$ & $\mathrm{n}=191$ \\
\hline None & $11(7)$ & 26 (14) \\
\hline Light & $56(37)$ & 75 (39) \\
\hline Moderate & $57(38)$ & $85(45)$ \\
\hline Heavy & $28(18)$ & $5(3)$ \\
\hline
\end{tabular}

* None to three or more of: overcrowding, lack of hot water, shared toilet, and dampness or poor repair.

†Light drinking was defined as up to 5 units of alcohol per week for women (10 units for men) and moderate drinking up to 21 units for women and 28 units for men. 
Table 3 Fetal, infant, and childhood influences on carotid intima-media thickness in men and women at age 49-51 years. Values are standardised regression coefficients (95\% confidence intervals)

\begin{tabular}{|c|c|c|}
\hline Independent variable & $\begin{array}{l}\text { Unadjusted in men } \\
\qquad(\mathrm{n}=154)\end{array}$ & $\begin{array}{l}\text { Unadjusted in women } \\
\qquad(\mathrm{n}=193)\end{array}$ \\
\hline \multicolumn{3}{|l|}{ Fetal life } \\
\hline $\begin{array}{l}\text { Self reported family history of angina, } \\
\text { heart condition, or stroke }\end{array}$ & $-0.09(-0.25$ to 0.07$)$ & $-0.04(-0.19$ to 0.10$)$ \\
\hline Social class at birth $\dagger$ & $-0.05(-0.21$ to 0.11$)$ & $-0.16(-0.30 \text { to }-0.02)^{\star}$ \\
\hline Poor housing conditions at birth & $0.10(-0.06$ to 0.26$)$ & $0.08(-0.07$ to 0.22$)$ \\
\hline Birth weightł & $-0.17(-0.33 \text { to }-0.02)^{*}$ & $-0.04(-0.18$ to 0.10$)$ \\
\hline \multicolumn{3}{|l|}{ Infancy and childhood } \\
\hline Social class at age 5 years & $0.02(-0.14$ to 0.18$)$ & $-0.09(-0.24$ to 0.05$)$ \\
\hline Poor housing conditions at age 5 years & $-0.06(-0.22$ to 0.10$)$ & $0.02(-0.12$ to 0.17$)$ \\
\hline Adverse life events in childhood & $0.06(-0.10$ to 0.22$)$ & $0.09(-0.06$ to 0.23$)$ \\
\hline Childhood infections & $-0.01(-0.17$ to 0.15$)$ & $-0.08(-0.22$ to 0.07$)$ \\
\hline Catch up growth in childhood§ & $0.12(-0.04$ to 0.28$)$ & $0.04(-0.11$ to 0.18$)$ \\
\hline
\end{tabular}

Regression coefficients expressed as standard deviation unit change in dependent variable produced by one standard deviation change in independent variable. Adjusted coefficients take account of significant and borderline significant covariates only $(P<0.10$ to enter, $P \geqslant 0.10$ to remove. Adjustment for early life and adult lifestyle takes account of other variables in same group, interaction between family history, fetal and childhood components (pathways A and B on figure) and of indirect effects mediated through adult socioeconomic position and lifestyle (pathway C). Adjustment for lifecourse also takes account of indirect effects mediated through adult biological risk markers (pathway D).

${ }^{*} \mathrm{P}<0.05$.

†In women: $-0.14(-0.28 \text { to }-0.01)^{*}$ when adjusted for early life and adult lifestyle and $-0.15(-0.29$ to $-0.02)^{\star}$ when adjusted for lifecourse.

łln men: -0.16 ( -0.31 to 0.00$)$ when adjusted for early life and adult lifestyle.

§Growth from birth to adulthood adjusted for achieved adult height and birth weight.

housing conditions at age 10 years (not shown), were unrelated to carotid intima-media thickness.

Social class at birth in women remained a statistically significant determinant of risk $(\mathrm{P}=0.03)$ after adjustment for adult lifestyle and biological risk markers. Birth weight in men, however, although retaining borderline significance after adjustment for adult socioeconomic position and lifestyle $(\mathrm{P}=0.05)$, was not significantly associated with carotid intimamedia thickness independently of other biological risk markers $(\mathrm{P}>0.10)$.
Socioeconomic position, lifestyle, and biological risk markers in adulthood

Waist to hip ratio and pack years of cigarette smoking in women were significant predictors of risk of cardiovascular disease (unadjusted $\mathrm{b}=0.24, \mathrm{P}=<0.01$ and $\mathrm{b}=0.20, \quad \mathrm{P}=<0.01$ respectively) (table 4) and remained so after adjustment for other significant risk factors. Exercise level was a significant predictor overall but not after adjustment. Carotid intima-media thickness in men was significantly related to systolic blood pressure and two hour glucose concentration, and these associations changed little after adjustment. After controlling for other lifestyle variables and risk markers, however, strong associations overall with waist to hip ratio, exercise level, and insulin and triglyceride concentrations became non-significant.

\section{Contribution of each stage of the lifecourse}

A family history of cardiovascular disease independently accounted for only $0.8 \%$ of total variance in carotid intima-media thickness in men and for $0.5 \%$ in women (table 5). Socioeconomic position at birth and birth weight accounted for a further $2.2 \%$ and $2.0 \%$ of variance respectively. The direct effects of circumstances and experience in infancy and childhood contributed $3.2 \%$ of variance in men and $2.2 \%$ in women. The overall contribution of all early life variables, including indirect effects mediated through adult socioeconomic position, lifestyle, and biological risk markers, was $9.2 \%$ for men and $4.7 \%$ for women.

Most variation in carotid intima-media thickness was explained exclusively by factors operating or measured in adulthood. Biological risk markers such as hyperlipidaemia, hypertension, and impaired glucose tolerance independently accounted for $9.5 \%$ of variance in men and $4.9 \%$ in women. Adult

Table 4 Adult influences on carotid artery intima-media thickness in men and women at age 49-51 years. Values are standardised regression coefficients (95\% confidence intervals)

\begin{tabular}{|c|c|c|c|c|c|c|}
\hline \multirow[b]{2}{*}{ Independent variable } & \multicolumn{3}{|c|}{ Men $(n=154)$} & \multicolumn{3}{|c|}{ Women $(n=193)$} \\
\hline & Unadjusted & Adjusted for adulthood & Adjusted for lifecourse & Unadjusted & Adjusted for adulthood & $\begin{array}{l}\text { Adjusted for } \\
\text { lifecourse }\end{array}$ \\
\hline \multicolumn{7}{|c|}{ Adult socioeconomic position and lifestyle } \\
\hline Cigarette smoking $\dagger$ & $0.06(-0.10$ to 0.22$)$ & & & $0.20(0.06 \text { to } 0.34)^{\star \star *}$ & $0.17(0.03 \text { to } 0.31)^{*}$ & $0.18(0.05 \text { to } 0.32)^{\star \star}$ \\
\hline Exercise level & $-0.20(-0.35 \text { to }-0.04)^{\star}$ & $-0.13(-0.28$ to 0.02$)$ & $-0.13(-0.28$ to 0.02$)$ & $-0.17(-0.31 \text { to }-0.03)^{*}$ & $-0.13(-0.27$ to 0.01$)$ & \\
\hline Physical inactivity & $0.08(-0.08$ to 0.24$)$ & & & $0.04(-0.10$ to 0.18$)$ & & \\
\hline Total energy from fat $(\%)$ & $0.10(-0.06$ to 0.26$)$ & & & $0.04(-0.10$ to 0.18$)$ & & \\
\hline \multicolumn{7}{|l|}{ Adult biological risk markers } \\
\hline Systolic blood pressure & $0.23(0.07 \text { to } 0.39)^{\star \star}$ & $0.20(0.05 \text { to } 0.35)^{\star}$ & $0.20(0.05 \text { to } 0.35)^{*}$ & $0.14(-0.01$ to 0.28$)$ & & \\
\hline Waist to hip ratio & $0.23(0.07 \text { to } 0.38)^{* *}$ & & & $0.24(0.10 \text { to } 0.37)^{\star * *}$ & $0.21(0.07 \text { to } 0.34)^{\star *}$ & $0.22(0.08 \text { to } 0.35)^{\star \star}$ \\
\hline \multicolumn{7}{|l|}{ Concentrations: } \\
\hline $\begin{array}{l}\text { Serum low density } \\
\text { lipoprotein cholesterol }\end{array}$ & $0.14(-0.02$ to 0.30$)$ & & & $0.04(-0.11$ to 0.18$)$ & & \\
\hline $\begin{array}{l}\text { Serum high density } \\
\text { lipoprotein cholesterolł }\end{array}$ & $-0.10(-0.26$ to 0.06$)$ & & & $-0.07(-0.21$ to 0.07$)$ & & \\
\hline Serum triglycerides $\ddagger$ & $0.16(0.01 \text { to } 0.32)^{*}$ & & & $0.10(-0.05$ to 0.24$)$ & & \\
\hline Plasma fibrinogen $\ddagger$ & $0.15(-0.01$ to 0.31$)$ & $0.14(-0.01$ to 0.30$)$ & $0.14(-0.01$ to 0.30$)$ & $0.06(-0.08$ to 0.20$)$ & & \\
\hline 2 Hour plasma glucose $\neq$ & $0.23(0.07 \text { to } 0.39)^{\star * *}$ & $0.19(0.04 \text { to } 0.34)^{*}$ & $0.19(0.04 \text { to } 0.34)^{*}$ & $-0.02(-0.16$ to 0.12$)$ & & \\
\hline Fasting serum insulin $\ddagger$ & $0.18(0.03 \text { to } 0.34)^{*}$ & & & $0.07(-0.08$ to 0.21$)$ & & \\
\hline
\end{tabular}

Regression coefficients expressed as standard deviation unit change in dependent variable produced by one standard deviation change in independent variable. Adjusted coefficients take account of significant and borderline significant covariates only ( $P<0.10$ to enter, $P \geqslant 0.10$ to remove). Adjustment for adulthood takes account of other variables in same group and of interaction between adult lifestyle and biological risk markers (pathway D on figure). Adjustment for lifecourse also takes account of indirect effects of early life experience (pathway $C$ ).

${ }^{*} \mathrm{P}<0.05 ;{ }^{* *} \mathrm{P}<0.01$.

†Adjusted for whether ever smoked or whether current drinker.

$\ddagger$ Log transformed. 
Table 5 Direct and overall contributions to variance in carotid intima-media thickness in men and women at age 49-51 years from circumstances and experiences at each stage of lifecourse. Values are percentage of variance explained (95\% confidence intervals)

\begin{tabular}{llll} 
& Source & Men $(\mathbf{n}=\mathbf{1 5 4})$ & Women $(\mathbf{n}=\mathbf{1 9 3})$ \\
\hline 1 & Self reported family history of cardiovascular disease & $0.75(0.00$ to 5.87$)$ & $0.46(0.00$ to 3.14$)$ \\
\hline 2 & Fetal life (socioeconomic position at birth and birth weight) & $2.16(0.08$ to 6.40$)$ & $2.00(0.13$ to 5.54$)$ \\
\hline 3 & Infancy and childhood (socioeconomic position, adverse life events, illnesses, and growth pattern) & $3.20(0.27$ to 6.78$)$ & $2.22(0.21$ to 5.04$)$ \\
\hline & Total early life (including indirect effects) & $9.15(2.42$ to 12.26$)$ & $4.73(2.12$ to 6.68$)$ \\
\hline 4 & Adult socioeconomic position and lifestyle & $2.27(0.42$ to 4.04$)$ & $5.86(0.81$ to 10.90$)$ \\
\hline & Total adult socioeconomic position and lifestyle (including indirect effects) & $3.42(0.51$ to 6.17$)$ & $7.56(2.08$ to 12.98$)$ \\
\hline 5 & Adult biological risk markerst unrelated to early life experience or adult lifestyle & $9.49(2.38$ to 14.21$)$ & $4.87(1.56$ to 7.39$)$ \\
\hline
\end{tabular}

Confidence intervals are bias corrected and are estimated by bootstrapping $\mathrm{R}^{2}$ statistic on 1000 repeated random samples of same size drawn with replacement from each dataset. Direct contributions from each stage of lifecourse are numbered to correspond with pathways 1-5 on figure. Overall contribution of early life variables includes indirect effects mediated through adult socioeconomic position and lifestyle (pathway C) and adult biological risk markers (pathway D). Overall contribution of adult socioeconomic position and lifestyle includes indirect effects mediated through biological risk markers (pathway D) but excludes early life influences. ${ }^{*}$ Cigarette smoking, alcohol consumption, exercise level, physical inactivity, and dietary fat intake.

†Waist to hip ratio, systolic blood pressure, concentrations of serum low density lipoprotein cholesterol, high density lipoprotein cholesterol, serum triglycerides, plasma fibrinogen, 2 hour plasma glucose, and fasting insulin at time of screening.

socioeconomic position and lifestyle accounted both directly and indirectly for $3.4 \%$ of variance in men and $7.6 \%$ in women.

\section{Discussion}

\section{Principal finding}

Adult lifestyle and biological risk markers measured in adulthood independently accounted for a greater proportion of total variance in carotid intima-media thickness at age 49-51 years than did the direct and indirect contributions of early life experience combined.

\section{Interpretation of results and comparison with other studies}

The smaller proportion of total variance accounted for by biological risk markers in women compared with men may reflect the lower risk for cardiovascular disease in this age group. The absence of significant associations with lipid, fibrinogen, glucose, and insulin concentrations in women might also be explained by the possible effects of oestrogen on lipid and glucose metabolism. ${ }^{27}$ Overall, 68\% (132 participants) of women in the sample were either premenopausal or had been receiving hormone replacement therapy for at least two years before screening.

Some of the variance that was independently accounted for by biological risk markers might be explained by tracking from childhood. The mediated effects of adult lifestyle, however, may be underestimated since such self reported variables are less reliably measured. The stronger association between carotid intima-media thickness and cigarette smoking in women is consistent with recent research, which has shown female smokers to be at greater risk of ischaemic heart disease. ${ }^{28}$

Socioeconomic position at ages 5 and 10 years was unrelated to carotid intima-media thickness. Although there was a significant association between carotid intima-media thickness and social class at birth in women, this effect was not observed in men. Non-significant adjusted associations with birth weight also provide little evidence that suboptimal growth in utero (a marker of suboptimal fetal nutrition) leads to increased intimal thickening of the carotid artery in later life independent of adult lifestyle and risk markers. Several explanations may account for these findings, which differ from many recent reports.

\section{Potential weaknesses of the study}

A programming effect that might have been shown by alternative measures of impaired fetal growth, such as placental to fetal weight ratio or ponderal index, ${ }^{29} 30$ cannot be excluded. We also cannot exclude early life effects that may have been mediated through underestimated aspects of adult lifestyle, although self reported smoking status was validated by measurement of the concentration of exhaled carbon monoxide. Overall, 109 study members (31\%) reported dietary energy intakes relative to predicted basal metabolic rate $^{31}$ of less than 1.1 (indicative of underreporting). Lack of information on families who moved out of Newcastle between 1947 and 1962 and an improvement in housing conditions over this period may also have reduced the strength of associations between socioeconomic position in childhood and adult health. Only 43\% (360 participants) of those invited attended for ultrasound examination, although this proportion is only slightly lower than that achieved from other traced populations. ${ }^{32}$

\section{Differences in study populations}

Although Martyn et $\mathrm{al}^{32}$ found a significant negative association between carotid stenosis and birth weight in a cohort born in Sheffield between 1922 and 1926 ,

\section{What is already known on this topic}

Numerous studies have shown statistically significant associations between low birth weight or socioeconomic disadvantage in childhood and adverse adult health outcomes

No studies, however, have quantified the proportion of variation in disease risk accounted for by factors operating in fetal life and at other stages of the lifecourse

\section{What this paper adds}

In this follow up study of a cohort of 154 men and 193 women born in Newcastle upon Tyne in 1947, early life variables such as birth weight and socioeconomic position in childhood were less strongly associated with cardiovascular disease risk at age 49-51 years than in other studies

Compared with factors operating in adulthood the independent contributions of circumstances and experiences in early life were small

Adult lifestyles and risk profiles should remain the main focus of intervention for reduction of risk of cardiovascular disease 
their analysis was confined to those who remained resident in the city, whereas the Newcastle sample included $25 \%$ of the 212 study members traced to addresses outside of the north of England. The limited overall effect of early life factors may also reflect the birth year of this sample. Most cohorts that have shown significant childhood contributions to adult mortality and disease risk are at least 10 years older. They experienced childhood in the prewar rather than postwar period when the dietary and other effects of material disadvantage and unemployment may have been more prevalent and severe. ${ }^{33}$

\section{Conclusion}

Although it is clearly important to promote good maternal and child health and to reduce the extent of socioeconomic deprivation in childhood, adult lifestyles and risk profiles should remain the main focus of intervention for reduction of risk of cardiovascular disease.

We thank Dr Fred Miller for his help, encouragement, and interest in the continuation of the Newcastle thousand families study (he was a principal investigator in 1947 and was continuously involved in the study until his death in March 1996); the staff of the Tyne and Wear county archive for the safekeeping of the original data; Theresa Patrick for secretarial and administrative assistance; Julian Smith for database management and computer programming; our research nurses, Jan Gebbie and Jean Gerrard, for carrying out the health checks; and Mavis Brown and her colleagues in the Wellcome Research Laboratory for assistance with clinical examinations.

Contributors: LP, AWC, and KGMMA conceived and directed the study and participated in the study design. DL managed the project, carried out all statistical analyses, wrote the first draft of the paper, and coordinated subsequent revisions. LP, MW, NU, SMAB, MC, DR, and AA participated in the study design and contributed to the analysis. HOD provided statistical advice and assistance. MC was involved in administering the health check and questionnaire survey, undertook the tracing of study members, and organised the abstraction of data from the original study archives. SMAB participated in the supervision and execution of the health checks. All authors contributed to the drafting of the final version of the paper. DL and LP will act as guarantors for the paper.

Funding: The current study was funded by the Wellcome Trust. Funding has also been provided by the Sir James Knott Trust (1992-5) and by the former Northern regional health authority (1993-5)

Competing interests: None declared.

1 Barker DJP. Mothers, babies and health in later life, 2nd ed. London: Churchill Livingstone, 1998.

2 Davey Smith G, Hart C, Blane D, Hole D. Adverse socioeconomic conditions in childhood and cause specific adult mortality: prospective observational study. $B M J$ 1998;316:1631-5.

3 Gliksman MD, Kawachi I, Hunter D, Colditz GA, Manson J-AE, Stampfer MJ, et al. Childhood socioeconomic status and risk of cardiovascular disease in middle aged US women: a prospective study. J Epidemiol Community Health 1995;49:10-5.

4 Kuh DL, Ben Shlomo Y. A lifecourse approach to chronic disease epidemology. Oxford: Oxford University Press, 1997.

5 Lamont DW, Parker L, Cohen MA, White M, Bennett SMA, Unwin NC, et al. Early life and later determinants of adult disease: a 50 year follow-up study of the Newcastle thousand families cohort. Public Health 1998;112:85-93

6 Williams S, Poulton R. Twins and maternal smoking: ordeals for the fetal origins hypothesis? A cohort study. BMJ 1999;318:897-900.

7 Ebrahim S. Use of B mode ultrasound of peripheral arteries as an end point in clinical trials. Br Heart J 1994;72:501-3.

8 Chambless LE, Heiss G, Folsom AR, Rosamond W, Szklo M, Sharrett AR, et al. Association of coronary heart disease incidence with carotid arterial wall thickness and major risk factors: the atherosclerosis risk in communities (ARIC) study, 1987-1993. Am J Epidemiol 1997;146:483-94.

9 Bots ML, Hoes AW, Koudstaal PJ, Hofman A, Grobbee DE. Common carotid intima-media thickness and risk of stroke and myocardial infarction: the Rotterdam study. Circulation 1997;96:1432-7.
10 Howard G, Sharrett AR, Heiss G, Evans GW, Chambless LE, Riley WA, et al. Carotid artery intimal-medial thickness distribution in general populations as evaluated by B-mode ultrasound. Stroke 1993;24:1297-304.

11 World Health Organisation monitoring trends and determinants in cardiovascular disease project. MONICA manual, part III, section 1. Geneva: World Health Organisation, Cardiovascular Diseases Unit, Nov 1990.

12 Petrie JC, O'Brien ET, Littler WA, de Swiet M, Padfield PL, Dillow MJ, et al Recommendations on blood pressure measurement. London: BMJ Publishing, 1990.

13 Prineas RJ, Crow RS, Blackburn H. The Minnesota manual of electrographic findings. Bristol: John Wright, 1982.

14 Friedewald WT, Levy RI, Fredrickson DS. Estimation of the concentration of low-density lipoprotein cholesterol in plasma, without use of the preparative ultracentrifuge. Clin Chem 1972;18:499-502.

15 Expert panel on detection, evaluation, and treatment of high blood cholesterol in adults. Summary of the second report of the national cholesterol education program (NCEP) expert panel on detection, evaluation and treatment of high blood cholesterol in adults (adult treatment panel II). JAMA 1993;269:3015-23.

16 Tanner JM, Whitehouse RH, Takaishi M. Standards from birth to maturity for height, weight, height velocity and weight velocity: British children, 1965, Parts 1 and 2. Arch Dis Childhood 1966:41:454-71, 613-35.

17 Gairdner D, Pearson J. A growth chart for premature and other infants. Arch Dis Childhood 1971;46:783-7.

18 Leon DA, Lithell HO, Vagero D, Koupilova I, Mohsen R, Berglund L, et al. Reduced fetal growth rate and increased risk of death from ischaemic heart disease: cohort study of 15000 Swedish men and women born 1915-29. BMJ 1998;317:241-5.

19 Eriksson JG, Forster T, Thomilehto J, Winter PD, Osmond C, Barker DJP. Catch-up growth in childhood and death from coronary heart disease: longitudinal study. BMJ 1999;318:427-31.

20 Lucas A, Fewtrell MS, Cole TJ. Fetal origins of adult disease-the hypothesis revisited. BMJ 1999;319:245-9.

21 Power C, Rodgers B, Hope S. U-shaped relation for alcohol consumption and health in early adulthood and implications for mortality. Lancet 1998;352:877.

22 Bingham SA, Gill C, Welch A, Cassidy A, Runswick SA, Oakes S, et al. Validation of dietary assessment methods in the UK arm of EPIC using weighed records. Int J Epidemiol 1997;26(suppl 1):137-51.

23 Kuh DL, Cooper C. Physical activity at 36 years: patterns and childhood predictors in a longitudinal study. J Epidemiol Community Health 1992;46:114-9.

24 Little RJA, Rubin DB. Statistical analysis with missing data. New York: Wiley, 1987.

25 Victora CG, Huttley SR, Fuchs SC, Olinto MTA. The role of conceptual frameworks in epidemiological analysis: a hierarchical approach. Int J Epidemiol 1997;26:224-7.

26 Rose GA. The diagnosis of ischaemic heart pain and intermittent claudication in field surveys. Bull World Health Org 1962;27:645-58.

27 Dubuisson JT, Wagenknecht LE, d'Agostino RA, Haffner SM, Rewers M, Saad MF, et al. Association of hormone replacement therapy and carotid wall thickness in women with and without diabetes. Diabetes Care 1998;21:1790-6.

28 Njolstad I, Arnesen E, Lund-Larsen PG. Smoking, serum lipids, blood pressure, and sex differences in myocardial infarction. A 12-year follow-up of the Finnmark study. Circulation 1996;93:450-6.

29 Martyn CN, Barker DJP, Osmond C. Mothers' pelvic size, fetal growth, and death from stroke and coronary heart disease in men in the UK. Lancet 1996;348:1264-8.

30 Phillips DIW, Barker DJP, Hales CN, Hirst S, Osmond C. Thinness at birth and insulin resistance in adult life. Diabetologia 1994;37:150-4.

31 Department of Health. Dietary reference values for food energy and nutrients for the UK. Report on health and social subjects, No 41. London: HMSO, 1992. 32 Martyn CN, Gale CR, Jespersen S, Sheriff S. Impaired fetal growth and atherosclerosis of carotid and peripheral arteries. Lancet 1998;352:173-8.

33 Hollingsworth D. The application of the newer knowledge of nutrition. In: Drummond JC, Wilbraham A, eds. The Englishman's food: five centuries of English diet. London: Pimlico, 1991:429-63.

(11 November 1999)

\section{Retraction}

First myocardial infarction in patients of Indian subcontinent and European origin: comparison of risk factors, management, and long term outcome

On 10 January 1998 we published a retraction (1998;316: $116)$ of this paper (1997;314:550-4) requested by the authors on the grounds that examination of the data had revealed inaccuracies and that the conclusions could not be sustained. The University of Leicester, where the work was done, established an inquiry, which has now confirmed that there were significant errors in the data and that the paper's findings were unsound. The errors arose in transcribing data from paper to digital form for statistical analysis, and the individual responsible has been censured. Following this incident the university has introduced a code of practice governing the management and conduct of research. 